Андрусь O.I. канд. пед. наук, доцент, Наиіональний технічний університет України «КПI»

\title{
ОСОБЛИВОСТІ ДЕРЖАВНОГО РЕГУЛЮВАННЯ ЦІНОУТВОРЕННЯ В ПРОМИСЛОВО РОЗВИНЕНИХ КРАЇНАХ
}

\section{SPECIFICS OF STATE REGULATION OF PRICING IN INDUSTRIALIZED COUNTRIES}

\section{ОСОБЕННОСТИ ГОСУДАРСТВЕННОГО РЕГУЛИРОВАНИЯ ЦЕНООБРАЗОВАНИЯ В ПРОМЫШЛЕННО РАЗВИТЫХ СТРАНАХ}

В роботі узагальнено економічні функиії держави в умовах розвиненого ринку в контексті державного регулювання процесів ціноутворення в промислово розвинених краӥнах світу. Досвід державного регулювання ціноутворення в США, Канади, Японії, ЄС та Китаю свідчить про значний вплив держави на означені процеси.

Цінове регулювання в розвинених країнах світу забезпечується адміністративноправовими та сочіально-економічними механізмами - визначальними інструментами економічної стабільності. Означені механізми державного впливу на процеси ціноутворення забезпечують ефективне використання обмежених ресурсів та ефективний споживчий попит, сприяють розв'язанню багатьох сочіально-економічних проблем, створюють умови для розвитку людини в суспільстві, підпорядковують виробництво сочіально значущих товарів $i$ послуг суспільним потребам з метою попередження інфляиії, монополізму виробників, зростання цін на сировинні та енергетичні ресурси, ефективного кредитування інвестиційних проиесів.

Результати дослідження можуть бути використані в подальшому вивченні проблем підвищення ефективності національного ціноутворення, зокрема обтрунтування методологічних основ, підвищення ефективності національного ціноутворення стратегічних та соціально значущих галузей, які безумовно потребують державної підтримки.

Ключові слова: ефективність, ціна, ціноутворення, державне регулювання, розвинені країни світу, законодавче забезпечення.

В работе обобщень экономические функции государства в условиях развитого рынка в контексте государственного регулирования процессов ценообразования в промышленно развитых странах мира. Опьт государственного регулирования ценообразования в США, Канадbl, Японии, ЕС и Китая свидетельствует о значительном влиянии государства на указанные проиессы.

Ценовое регулирование в развитых странах мира обеспечивается административноправовыми и социально-экономическими механизмами - определяющчими инструментами экономической стабильности. Указанные механизмы государственного влияния на процессы ценообразования обеспечивают эффективное использование ограниченньх ресурсов и эффективный потребительский спрос, способствуют решению многих социально- 
экономических проблем, создают условия для развития человека в обществе, подчиняют производство сочиильно значимых товаров и услуг общественным потребностям с иелью предупреждения инфляции, монополизма производителей, роста иен на сырьевые $и$ энергетические ресурсы, эффективного кредитования инвестиционных процессов.

Результаты исследования могут быть использованы в дальнейшем изучении проблем повышения эффективности национального ценообразования, в частности обоснование методологических основ, повышение эффективности национального ценообразования стратегических и социально значимых отраслей, безусловно нуждаются в государственной поддержке.

Ключевые слова: эффективность, цена, ценообразование, государственное регулирование, развитые страны мира, законодательное обеспечение.

This work contains summarizes of the economic functions of the state in terms of developed market in the context of state regulation of pricing in industrialized countries. The experience of state regulation of pricing in the USA, Canada, Japan, EU Europe and China indicates significant impact on the state expressed by processes.

The price adjustment in the industrialized world provided administrative-legal and socioeconomic mechanisms - crucial instruments of economic stability. The mentioned mechanisms of state influence on pricing processes ensure efficient use of limited resources and effective consumer demand, contribute to the solution of many social and economic problems, create conditions for the development of human society, dominate the production of socially important goods and services the public needs to prevent inflation, monopoly producers, higher prices for energy and raw materials, effective credit investment processes.

Results of the study can be used to further study issues improve national pricing, including study methodological foundations, improve national pricing policy and socially important sectors that definitely need government support.

Keywords: efficiency, price, pricing, government control, developed countries of the world, legislative providing.

Вступ. Сучасний розвиток соціально-економічних систем зумовлює потребу державного регулювання економічних процесів. Державний вплив на економічні процеси виступає цільовою системою законодавчого, виконавчого та контрольного характеру, яка забезпечує інтенсивне економічне зростання, економічну та соціальну стабільність, належне міжнародне становище держави. Ціни та ціноутворення - індикатор ефективності економічних процесів, який відбиває ефективність державного регулювання економіки.

Аналіз наукової літератури свідчить, що проблема державного регулювання ціноутворення $є$ предметом численних наукових досліджень, які відображають різні іï аспекти. Зокрема, проблеми розвитку процесу ціноутворення історично знайшли відображення в працях А. Сміта, Д. Рікардо, К. Маркса, А.Маршалла, Дж.М. Кейнса, Дж.К. Гелбрейта. Висвітленню проблем теорії та практики сучасного ціноутворення присвячені дослідження В.М. Гальперіна, В.С. Ссіпова, I.А. Єрухимовича, I.В. Ліпсіца, А.Д. Чудакова, Л.О. Шкварчук. Ефективність 
управління цінами та ціновою політикою досліджена в роботах Т.Г. Євдокимової, Г.А. Маховикової, І.А. Желтякової, С.В. Переверзевої, Я.В. Литвиненка, В.Л. Корінєва. Обгрунтування стратегії і тактики ефективного ціноутворення розкрито в роботах Т.Т. Негла, Р.Дж. Долана, Г. Саймона. Практичний досвід формування конкурентних цінових переваг підприємства висвітлено в працях М.В. Марна, Е.В. Регнера, К.К. Завади. Дослідження проблем сучасного державного регулювання цін у зарубіжних країнах подано в роботах М.Ю. Лева, Є.Д. Чувиліна, В.Г. Дмитрієвої.

Отже, ефективне ціноутворення сприяє підпорядкуванню виробництва суспільним потребам. А адекватний рівень цін будь-якої економіки забезпечує іiі економічне зростання, ефективне конкурентне середовище, орієнтує виробництво на інноваційний зміст, сприяє скороченню витрат виробництва, прискоренню обігу виробничого капіталу, підвищенню якості товарів і послуг, а також їх споживчого попиту.

Постановка завдання. Такий стан проблеми детермінує потребу аналізу особливостей державного регулювання цін у промислово розвинених країнах 3 метою окреслення шляхів його оптимізації в національній економіці. Теоретичні висновки мають бути зроблені 3 позицій збереження надбань сучасної економічної науки. Мета статті - виявити та узагальнити особливості державного регулювання сучасного ціноутворення промислово розвинених країн.

Методологія. В ході наукового пошуку були використані ряд методів дослідження: а) теоретичні - системно-структурний (класифікація, систематизація) та ретроспективний аналіз економічної літератури, нормативноправових документів, дисертаційних досліджень для визначення концептуальних положень досліджуваної проблеми; б) емпіричні - методи математичної статистики для кількісного та якісного аналізу емпіричних даних.

Методологічну основу дослідження склали: сучасні філософські положення i принципи єдності теорії та практики про людину як суб'єкт діяльності, пї активність у процесі пізнання; загальнотеоретичні висновки філософії, педагогіки, психології про всебічне формування і розвиток людини; концепції демократизації та гуманізації освіти і виховання.

Теоретичну основу дослідження складають праці провідних вітчизняних та зарубіжних дослідників 3: фундаментальних проблем професійної освіти (В.П.Андрущенко, С.У. Гончаренко, І.А. Зязюн, В.Г. Кремінь, Н.Г. Ничкало, С.О.Сисоєва); теорії організації та змісту освіти (А.М. Алексюк, С.У.Гончаренко В.В.Краєвський, І.Я. Лернер, А.В. Петровський, М.М. Скаткін); проблем теорії і практики професійної підготовки фахівців у технічних університетах 
(М.З.Згуровський, О.Е. Коваленко, В.С. Ледньов, Е.В. Лузік, О.Г.Романовський, Л.Л.Товажнянський та ін.); теорії організації та змісту модульного навчання у практиці вищої освіти (А.М. Алексюк, В.І. Бондар, Л.М. Романишина, В.Д.Чернілевський, П.А. Юцявічене та ін.); розвитку економічної освіти молоді (В.Я. Бобров, Г.О. Ковальчук, В.А. Козаков, Н.А. Побірченко, О.О.Романовський, та ін.); основ організації та методичного забезпечення самостійної роботи студентів (А.М. Алексюк, С.У. Гончаренко, В.А. Козаков, А.В. Петровський та ін.); розвитку творчості студентів (І.Я. Лернер, С.О.Сисоєва, М.М. Скаткін ін.); організації групової діяльності студентів (М.В.Артюшина, О.Г. Ярошенко, Л.Б. Волошко, Т.Б.Поясок), використання інтерактивних методів навчання (O.I. Пометун, А.В.Свєтлорусова, П.М.Щербань).

Результати дослідження. Розвиток ринкових відносин в Україні зумовив потребу інституційного обгрунтування державного регулювання цін та ціноутворення національної економіки. Однак для забезпечення ефективності цього процесу доцільно проаналізувати, вивчити та узагальнити особливості державного регулювання ринкових процесів у промислово розвинених країнах та ціноутворення зокрема. Важливо осмислити та узагальнити надбання економічної науки, наукових положень та практичного досвіду ціноутворення розвинених країн, накопичених в умовах ринку для звільнення від застарілих підходів, збереження й використання всього актуального.

Аналіз досвіду розвинених країн свідчить, що рівень, форми й методи державного регулювання ринкових процесів і процесів ціноутворення, зокрема, суттєво відмінні в різних країнах у різні періоди. Водночас, аналіз економічних джерел дозволяє узагальнити економічні функції держави в умовах розвиненого ринку, зокрема, держава:

- законодавчо забезпечує нормативно-правові основи розвитку ринкової економіки та законодавчо встановлює інституційні «правила гри» ринкових суб'єктів;

- сприяє стабільному економічному зростанню, здоровій конкуренції та підприємництву, обмеженню монополізму, втілюючи в економічні процеси антициклічні заходи економічного регулювання, попередження кризових спадів, масового безробіття та інфляції за допомогою грошово-кредитної та податкової систем;

- засобами прогресивного оподаткування та системою перерозподілу накопичених бюджетних коштів сприяє подоланню недоліків вільного ринку, який не забезпечує соціально необхідну стабільність, платіжний попит малозабезпечених громадян, соціально сприятливий рівень освіти, охорони здоров’я, науки, культури тощо; 
- компенсує відсутність ефективного впливу ринку та приватного капіталу, зокрема на збереження довкілля, розвиток соціально значущих сфер суспільства, забезпечення оборони та вдосконалення державного управління економічними процесами;

- суспільно заохочує споживання корисних товарів i послуг та водночас законодавчо обмежує споживання шкідливих для здоров'я товарів внутрішнього виробництва та імпортованих;

- забезпечує заходи регулювання зовнішньоекономічних відносин 3 метою захисту внутрішнього ринку від конкуренції іноземних виробників та стимулює експортну діяльність національних підприємств.

Досвід розвинених країн світу, зокрема країн США, Канади, Японії, Свропи, Китаю свідчить про значний вплив держави на ринкові процеси 3 метою мобілізації ресурсів суспільства в умовах довготермінового планування для забезпечення базового рівня розвитку людини в суспільстві [1].

Цінове регулювання в розвинених країнах світу - дієвий інструмент економічної стабільності, який реалізується передусім 3 метою попередження зростання інфляції, монополізму виробників, зростання цін на сировинні та енергетичні ресурси, ефективного кредитування інвестиційних процесів.

У сучасних країнах розвиненої ринкової системи сформована складна система цін, яка зумовлюється як внутрішньою специфікою господарської діяльності підприємств, так і особливостями зовнішнього інституційного поля національних господарств $[1,3]$.

Уряди втілюють певні адміністративно-правові та соціально-господарські механізми, які дозволяють аналізувати як співвідношення та рівні цін, так i процеси внутрішнього ціноутворення. Способи та методи державного регулювання цін в різних країнах сформувалися історично, мають національні, кліматичні орсобливості, орієнтовані на сировинні на політико-економічні умови та обумовлені місцем держави в світовій економіці.

Аналіз наукових досліджень дозволяє зробити висновок, що в промислово розвинених країнах державний контроль над цінами товарів національних економік здійснюється від 5\% до 50\% [1;3].

Традиційно найменша частка державного впливу на ринкові процеси (близько 5\%) належить США. Регулювання цін продукції аграрного сектора здійснює Міністерство сільського господарства. Контроль за цінами інших галузей національної економіки здійснює Антитрестове управління Міністерства юстиції та Федеральна торгова комісія. Штатам надано повноваження контролю тарифів на електроенергію. Державний вплив на ціноутворення в США здійснюється переважно на продукцію природних монополій (енергетика), фермерські ціни, на 
рівні штатів - електроенергія, міжміські автомобільні та залізничні перевезення. А спеціальні підрозділи Федеральної торгової комісії застосовують пряме державне регулювання цін на електроенергію, комунальні послуги, продукцію аграрного сектора, певні товари роздрібної торгівлі [7].

Хоча уряд Японії дотримується політики обмеження державного впливу на ринкові процеси, однак не віддає на відкуп стихійним ринковим силам та структурам процеси формування цін. Тому близько 20\% споживчих цін Японії регулює держава. Уповноваженим органом регулювання цінотворчих процесів, планів, проектів з координуванням цінової політики Японії $є$ Бюро цін при Агенції з економічного планування, яке щорічно публікує аналітичну «Доповідь про ціни» та надає споживачам інформацію про ціни он-лайн. Значна частина регульованих цін Японії припадає на продукцію аграрного сектора - рис, пшеницю, м'ясні та молочні продукти і навіть питну воду. Також держава регулює тарифи на електроенергію, газ, залізничні перевезення. Особлива увага уряду Японії приділяється й регулюванню цін на освітні та медичні послуги. Водночас, для підтримки національного виробника застосовується кількісні обмеження імпорту м'яса, цукру, шовку-сирцю тощо. Держава також створює буферні запаси цих продуктів на період спаду цін та розпродає запаси в період їх зростання. Державними органами Японії встановлюються й рекомендовані ціни, зокрема, на рис та пшеницю - парламентом за поданням прем'єр-міністра, на м'ясні та молочні продукти - міністром землеробства, лісництва та рибальства. Рекомендовані ціни знаходяться під постійним контролем повноважних органів та залежно від економічної ситуації мобільно переглядаються [8].

Аналіз цінотворчих процесів країн Європейського Союзу свідчить про наднаціональний контроль над цінами в рамках співдружності, який здійснюють комісії $€ C$, а рішення приймає Рада Міністрів $Є С$ на рівні міністерств країнучасниць. В межах Свропейського Союзу на національному рівні встановлюється до $15 \%$ цін. Зокрема, контроль за цінами країн Європейського Союзу здійснюється на переважну частину продукції аграрного сектора (від 88 до 97\%) [4, с.138-154].

Передусім здійснюється нагляд за цінами продукції землеробства (пшениця, ячмінь, жито, кукурудза, рапс, соняшник), крупний рогатий скот, молоко, цукор, оливкове масло. Крім сільськогосподарської продукції в країнах ЄС 1980 року здійснюється над національний контроль за цінами на вугілля, сталь та прокат шляхом квотування, встановлення твердих обов'язкових цін - базисних для всіх країн-членів ЄС. Відхилення цін виробників продукції металургії не може перевищувати $5 \%$.

Крім чорної металургії регулювання цін на продукцію виробників СС здійснюється в текстильній промисловості, суднобудуванні, виробництвах 
легкових автомобілів, побутової техніки, устаткування з числовим програмним управлінням. Значна увага приділяється також контролю за діяльністю підприємств, які об’єднуються, зливаються або опосередковано виявляють вплив на процеси ціноутворення.

Стосовно державного регулювання цін на послуги природних монополій, то за рекомендацією $Є С$ у більшості країн не практикуються дотації, а обгрунтовуються ціни на товари та послуги суспільного використання. Це стосується електро-, водо, газопостачання, служби зв'язку, транспорту тощо.

3 метою підвищення тривалості життя населення в країнах ЄС розробляються нові, більш якісні методики лікування, які потребують більш досконалих лікарських засобів. Однак при цьому збільшується вартість лікування та медичного обслуговування. Для оптимізації ціноутворення на фармацевтичну продукцію прийнята відповідна директива, яка обумовлює продаж лікарських препаратів. Водночас, в країнах СС запроваджено різні системи оплати вартості лікарських препаратів населенням: спільне страхування, плата за отримання рецепта та спільна оплата в межах відносних (орієнтовних) цін. Одним із заходів ціноутворення лікарських препаратів $\epsilon$ регулювання рівнів рентабельності фармацевтичних компаній. Так, в Іспанії діє принцип обмеження частки прибутку в ціні від 12 до 18\%, тоді як у Великій Британії регулюються прибутки компанії в цілому.

Таким чином, процеси ціноутворення СС сприяють підвищенню ефективності сучасного ринку, забезпеченню споживачів суспільно значущими товарами й послугами. Водночас, розгляд специфіки цінотворчих процесів країн ЄС дозволяє виявити національні особливості формування цін у Європейській співдружності.

Так, в Австрії державою регулюється близько 10\% цін на товари й послуги національної економіки. Ціни на товари i послуги державних монополій (тютюнові вироби, сіль, поштові збори, телефонні, телеграфні та залізничні тарифи) встановлює парламент власними рішеннями. Міністерство фінансів законодавчо контролює ціни на алкогольні напої. А контроль за виконанням встановленого рівня цін покладено на місцеві органи земель та поліцію. Штучне завищення цін передбачає законодавчу відповідальність та штрафні санкції [11].

Державному сектору економіки Франції належить незначна питома вага у ВНП. Передусім це - природні монополісти (газова промисловість, транспорт, електроенергетика), а також деякі конкурентні ринкові галузі (національний та комерційні банки, страхові компанії, окремі підприємства). Для монополістів держава встановлює суспільно прийнятні економічні параметри, a для конкурентних галузей забезпечує ефективні інституційні основи. Співвідношення між регульованими та вільними ринковими цінами орієнтовно $20 \%$ до 80\%. Упродовж 30 повоєнних років державне регулювання ціноутворення було 
невід'ємною складовою політики «дирижизму». На певних етапах розвитку регулювалися навіть всі ціни. Досвід цінового стимулювання промислового розвитку Франції узагальнює такі етапи:

- договірні програми (1966-1970 рр.) (підприємства самостійно встановлювали ціни, однак виконували ряд компромісів стосовно рівня заробітних плат та інвестицій);

- договірні ціни (1971р.) (встановлення урядом лімітів зростання цін на період їх дії, при цьому зростання цін становило близько 1,5 \%);

- угоди-програми (1972-1976 рр.) (комбінована система нормування ціноутворення, стимулювання продуктивності праці та заохочення до гнучкого режиму ціноутворення);

- всезагальний контроль над цінами (1976р.) (встановлення повного державного контролю над цінами на чотири місяці, як надзвичайний захід боротьби з інфляцією);

- помірні компроміси (1977-1978 рр.) (лібералізація цін, можливість адаптації цін до рівня кожного підприємства).

Процес лібералізації цін тривав у першій половині 80-х років, що дозволило звільнити від державного регулювання $80 \%$ цін промислової продукції. Особливості сучасного ціноутворення Франції зорієнтовані передусім на економічний аналіз механізму ринку, встановлення правової відповідальності господарських суб'єктів за порушення конкурентної поведінки, дотримання принципу «економічної свободи» [6].

Досвід державного цінового регулювання Швейцарії свідчить, що законодавчо регулюються ціни майже 50\% обсягу товарного виробництва. Особлива увага приділяється державному сектору економіки. Зокрема, аграрному сектору, який захищається від зовнішнього конкурентного тиску шляхом квотування ввозу продукції агропромислового комплексу, переважно овочів i фруктів. Дотаційними у Швейцарії є також тарифи на залізничний транспорт $\mathrm{i}$ будівництво доріг. Контроль за рівнем цін здійснюють не тільки державні органи нагляду, але й суспільні організації, як-то Фонд захисту прав та інтересів споживачів [3, с.169-178].

Частка регульованих цін у Данії незначна, складає біля 6\%. Ціни формуються переважно в умовах вільної конкуренції. Головний напрям впливу держави на процеси ціноутворення - захист конкуренції від діяльності монополій. Діючий Закон про ціни та прибутки (1974р.) регламентує певний порядок формування цін. Порушення встановленого порядку обкладається штрафними санкціями та арештом майна. Система державних дотацій у Данії практично відсутня. Однак, існує державна система державної підтримки фермерів (надання державних 
гарантій на позики, капітальне будівництво, впровадження енергозберігаючих систем, пільгові кредити молодим фермерам, які придбали власне господарство тощо). Відповідно до Консолідованого Закону Данії про захист національного здоров'я значна увага приділяється й ціноутворенню лікарських препаратів та виробів медичного призначення [1, с.169-178].

Контрольовані державою ціни в Іспанії складають 10\% загальної структури споживчих цін. Фіксовані иіни встановлює міністерство економіки та фінансів, передусім на предмети першої необхідності (молоко, хліб тощо). Списки регульованих цін товарів та послуг постійно оприлюднюються в бюлетенях комерційної інформації. Дозвільні ціни природних монополій формує урядова комісія 3 економічних питань. Належність природних монополій державі зумовлює контроль за тарифами електроенергії, газу, бензину, керосину, дизельного палива, нафти для виробництва добрив, а також послуг залізничних, автомобільних, пасажирських та вантажних перевезень, поштових послуг. Вища рада 3 цін Міністерства економіки та фінансів встановлює повідомлювальні ціни на рослинні масла, фуражне зерно, пастеризоване молоко та мінеральні добрива. Ïx зміна можлива лише на основі повідомлення законодавчого органу, але не раніше, ніж за місяць до їх впровадження. Ціни на послуги водопостачання, медичного, оздоровчого обслуговування населення, міські автомобільні та залізничні пасажирські перевезення є місиевими. Їх встановлюють провінційні комісії з ціноутворення [8].

Близько 20\% цін споживчих товарів та послуг Греції регулюється державою. Значна увага приділяється регулюванню цін продукції сільського господарства. Так, пшениця, тютюн, родзинки, сільськогосподарська техніка та запасні частини до неї $є$ предметом державного регулювання цін. Тарифи на електроенергію, громадський транспорт, зв'язок, поштові послуги, послуги перевезення авіаліній, каботажного плавання, бензини, мазут, дизельне пальне також регулюються державою. Значному регулюванню цін у Греції піддаються товари та послуги туристичного бізнесу та суміжних галузей, зокрема харчосмакових товарів, безалкогольних напоїв, ресторанів, барів, автостоянок, орендної плати за житло тощо [1, с.88-96].

Висновки. Наукова новизна дослідження полягає в систематизації результатів аналізу особливостей державного регулювання сучасного ціноутворення промислово розвинених країн, що дозволяє узагальнити ряд висновків:

1. Переважна більшість країн розвинутого ринку регулює цінотворчі процеси на законодавчому рівнв, орієнтуючись на певні принципи, методи та порядок формування цін.

2. Уповноважені державні органи промислово розвинених країн здійснюють стратегічне, тактичне регулювання ціноутворення, а також забезпечують 
формування цін на соціально значущі товари і послуги.

3. Законодавче забезпечення регулювання ціноутворення у більшості промислово розвинених країн світу було прийнято та діє з середини $\mathrm{XX}$ століття, а у Великій Британії, США та Франції - 3 кінця XIX століття зі змінами та доповненнями, орієнтовано на особливості економічної політики.

4. Порівняльний аналіз досвіду ціноутворення ряду розвинених країн світу $з$ досвідом регулювання цінотворчих процесів в Україні свідчить, що незважаючи на низку прийнятих законодавчо документів стосовно проблем національного ціноутворення спостерігається недостатня ефективність регулювання та законодавчого забезпечення зазначених процесів з метою підтримки ділової активності підприємницького сектору економіки. Суб'єкти господарської діяльності в Україні практично не мають повноважень впливу на ефективність національного ціноутворення.

Результати дослідження мають теоретичне та практичне значення, оскільки можуть бути використані 3 метою підвищення ефективності національного ціноутворення в Україні, забезпечення інтересів виробників i споживачів доцільно розробити й законодавчо прийняти національну цінову стратегію.

Результати дослідження можуть бути використані в перспективних подальших наукових розробках при вивченні проблем підвищення ефективності національного ціноутворення, зокрема обгрунтування методологічних основ, модернізації національного механізму формування цін стратегічних та соціально значущих галузей, які безумовно потребують державної підтримки.

\section{Лiтература:}

1. Чувилин Е. Д. Государственное регулирование и контроль цен в капиталистических странах / Е. Д. Чувилин, В.Г. Дмитриева. - М. : Финансы и статистика, 1991. - 350с.

2. Липсиц И. В. Ценообразование (Управление ценообразованием в организации) / И. В. Липсиц ; 3 изд. переаб. и доп. - М. : Экономисть, 2004. - 448c.

3. Лев М. Ю. Регулирование ценообразования в развитых странах / М. Ю. Лев. - СПб. : ГУЭиФ. - 2004. - 430 с.

4. Евдокимова Т.Г. Теория и практика управления ценами / Т. Г. Евдокимова, Г. А. Маховикова, И. А. Желтякова, С. В. Переверзева. - СПб. : Издательский дом «Нева» - 2008. $208 \mathrm{c}$.

5. Долан Р. Дж. Еффективное ценообразование / Р. Дж. Долан, Г. Саймон. - М. : Издательство «Финансы», 2005. - 416 с.

6. Трушицын С. Н. Особенности государственного регулирования цен во Франции. / С. Н. Трушицын // Вопросы экономики. - 1992. - №6. - С.52 - 59.

7. Официальный сайт Института США и Канады Российской академии наук (ИСКРАН). [Электронный ресурс]. - Режим доступа: www.iskran.ru 
8. Body of knowledge on infrastructure Regulation. [Electronic resource]. - Access: http://www.regulationbodyofknowledge.org/

9. Une loi de une un droit régularisation et un prix (1945, dans une rédaction un 71 an) Une Belgique senat, 07.12.1971 / http://www.senate.be/

10. Gesetz über Preisen das 1948 in Schriftleitung das 1988. Ausfertigungsdatum: 10.04.1948.

11. United Kingdom's Office for National Statistics (ONS) [Electronic resource]. - Access: http://www.ons.gov.uk/ons/taxonomy/index. 